\title{
Test Excavations at Site 41TT87 on County Road 211 Titus County, Texas
}

\author{
Milton Bell
}

Follow this and additional works at: https://scholarworks.sfasu.edu/ita

Part of the American Material Culture Commons, Archaeological Anthropology Commons, Environmental Studies Commons, Other American Studies Commons, Other Arts and Humanities Commons, Other History of Art, Architecture, and Archaeology Commons, and the United States History Commons

Tell us how this article helped you.

This Article is brought to you for free and open access by the Center for Regional Heritage Research at SFA ScholarWorks. It has been accepted for inclusion in Index of Texas Archaeology: Open Access Gray Literature from the Lone Star State by an authorized editor of SFA ScholarWorks. For more information, please contact cdsscholarworks@sfasu.edu. 


\section{Test Excavations at Site 41TT87 on County Road 211 Titus County, Texas}

\section{Licensing Statement}

This is a work produced for the Texas Department of Transportation (TxDOT) by the report producer. TxDOT and the report producer jointly own all rights, title, and interest in and to all intellectual property developed under TXDOT's contract with the report producer. The report may be cited and brief passages from this publication may be reproduced without permission provided that credit is given to both TxDOT and the report producer. Permission to reprint an entire chapter, section, figures or tables must be obtained in advance from either the Supervisor of the Archeological Studies Branch, Environmental Affairs Division, Texas Department of Transportation, 125 East 11th Street, Austin, Texas, 78701 or from the report producer. 
TEST EXCAVATIONS AT SITE 41TT87

ON COUNTY ROAD 211

TITUS COUNTY, TEXAS

\author{
by \\ Milton Bell
}

Texas

State Department of Highways and Public Transportation Highway Design Division

January, 1990

Austin, Texas 


\section{TABLE OF CONTENTS}

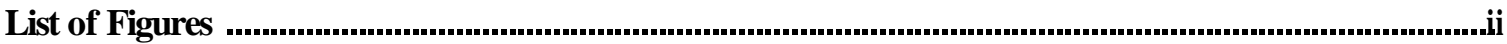

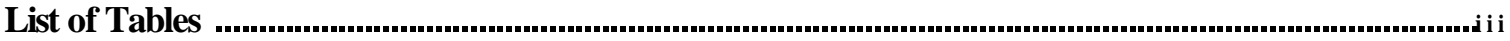

Abstract

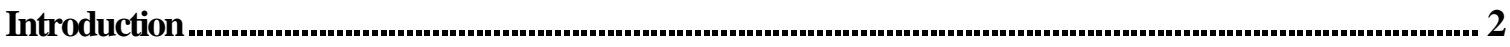

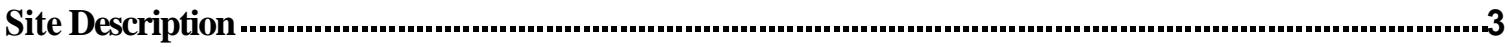

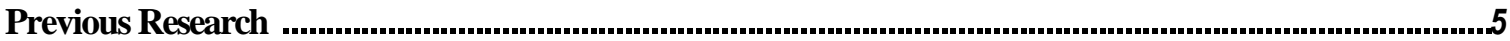

Testing Procedures .......................................................................................................................................6

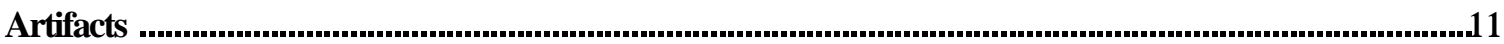

Summary and Recommendations ..................................................................................................... 16

References Cited .......................................................................................................................................17 


\section{LIST OF FIGURES}

FIGURE 1. Location of Site41TT87 in Titus County

FIGURE 2. Contour map of Site 41TT87 showing CR 211 and excavation areas . .7

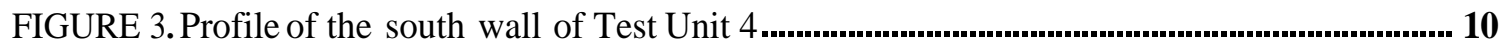

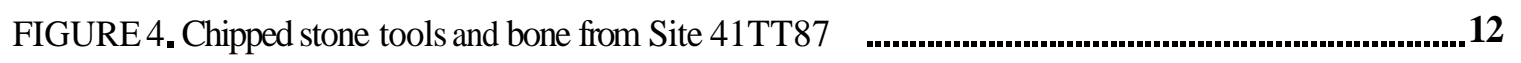

FIGURE 5. Ceramic artifacts from Site 41TT 87 .......................................................................14 


\section{LIST OF TABLES}

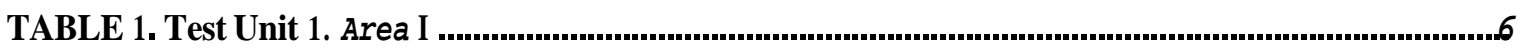

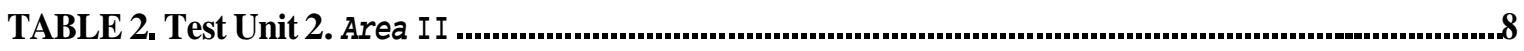

TABLE 3. Test Unit 3. Area I I ............................................................................................... 8

TABLE 4. Test Unit 4. Area II .................................................................................................9

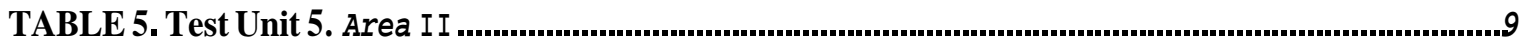




\begin{abstract}
Archaeological testing of Site 41T T 87 was performed during May and J uneof 1989 by the State Department of Highways and Public Transportation (SDHPT). These investigations were prompted by plans by Titus County and theSDHPT to replace three wooden bridges and reconstruct the County Road 211 roadway which crosses While Oak Creek bottom. Five 1 meler square test units were excavaled which produced a number of prehistoric ceramic sherds, chert flakes, and bifacial tools of which the Gary dart point type is dominant. No prehistoric features were found and the areas available for study all exhibited prior disturbance. Historic artifacts were also recovered and included wire and cut nails, glass, sheet metal fragments, and earthenware and stonewareceramic sherds. The major portion of the site containing the prehistoric componentlies outside the right-of-way. Those portions of the site within the right-of-way are not believed to be eligible for inclusion within the National Register of Historic Places. No further investigationsare recommended.
\end{abstract}




\section{INTRODUCTION}

Investigationsat Site 41TT 87 were prompted by plans to replace three substandard bridges on Titus County Road 211 at White Oak Creek, White Oak Slough and White Oak Creek Relief. This off-systems project will be funded through the Federal Highway Administration and Titus County and built by the State Department of Highways and Public Transportation (SDHPT). The White Oak Creek Bridge was judged to be unsafe in 1986 and was closed by Titus County. In 1988. the $2094 \mathrm{ft}$. timber structure burned, thus permanently closing CR 211 to through traffic.

The planned project will replaceall three bridges and the roadway across the White 0 ak Creek bottoms. Total length for the project is approximately 0.7 mile. The new roadway will have a crown width of 28 feet as opposed to the existing 17 to 20 feet oil surface and will be raised a maximum of 8 feet above the present roadway surface.

Since the project will require an additional 11.7 acres of right-of-way, an archaeological survey of the project was conducted in April, 1988. No unrecorded archaeologicalsites were found. However, Site 41TT87, a site recorded by the author in 1974, appeared to be partially within the northern limits of the project and testing was recommended. In May, 1989, right-of-entry agreements were secured with the two landowners and testing began in J une. Testing of Site 41TT87 was performed in accordance with 36 CFR, Part 800, and the M emorandum of Understanding between the SDHPT and the Texas A ntiquities Committee. A total of 15 man-days were spent on the test excavations. 


\section{SITE DESCRIPTION}

Site 41TT87 is situated on a low prominence, an alluvial terrace, whichoverlooks Big Slough and W hite Oak Creek bottom to the immediate south (Fig. 1). Mount Pleasant, county seat of Titus County, is approximately 10 miles farther south.

White Oak Creek is a major drainage for the northern portion of Titus County. The stream begins in Hopkins County near Sulphur Springs and flows into the Sulphur River in Bowie County, a distance of some 80 miles. There are approximately 70,000 acres included in the floodplain of White Oak Creek. The principal vegetalion in the project area consists of post oak, pin oak, water oak, and sweet gum with a mixed understory of briars, sumac, poison ivy and grasses.

The terrace depositcontaining the site is elevated above the flood plain to the extent that it is rarely covered by floodwaters. The floodplain of White O ak Creek is very wide which lessens the incidence of extremely high flood water. The soils in the area are a mixture of colluvial and alluvial sands, silts, and clays (Fenneman. 1938) and are often in excess of a meter in depth.

County Road 211 was originally State Highway 26. The road reverted to county service with the completion of US 271, the principal north-south connector between Mount Pleasant and Paris. The earlier construction of SH 26 probably destroyed much of Site 41TT87 and contributed to additional damage through erosion.

When the site was first visited by the author, several years beforeit was recorded, it was the location of a small farm house and barn and a vegetable garden. It was the garden and the road construction which first brought the site to the attention of local collectors. who reportedly dug into several burials in the "road ditch." Today. both house and barn have been removed and all traces of the garden are covered by a thick growth of weeds and grass and small persimmon sprouts.

White Oak Slough, also called Big Slough. is the nearest permanent water source. Two small, linear ponds east of the site are probably the remains of an earlier slough. The area east of the site is a separate ecotone consisting of a grassy wetland with reeds and rushes growing near small patches of standing water. Logging operations during the last 80 years have removed most of the trees from this area. The areas north and west of the site are rolling pasturelands. 


\section{This Page Redacted Per THC Policy}




\section{PREVIOUS RESEARCH}

TitusCounty is located in the northern heartland of the Caddoan "culture area" of East Texas. Besides this rich heritage from the late prehistoric period, all culture periods, from Paleo-Indian to Historic Indian, are represented.

Unfortunately,due to the abundance of Caddoan sites, this area of northeast Texas has been the scene of intense "pot-hunting" by collectors. In some areas it is difficult to find undisturbed sites as the destruction continues.

Much of this collecting began in the 1930s during the depression when a number of people realized that a market existed for ceramic vessels and other artifacts. It was also a time of great archaeological activity by professional archaeologists throughout the state but particularly in northeast Texas.

Most of the professional work in Titus County during this period was carried out by A. T. Jackson for the University of Texas under the auspices of the WPA. Most of what is known about the area today is a result of this work although Jackson and others concentrated on the excavation of burials.

Apparently, no major field work was done in Titus County until the late 1960swhen the office of the State Archaeologist, then a part of the State Building Commission, carried out a number of archaeological surveys in the Cypress Creek Basin in anticipation of reservoir construction. During the 1970s, this effort continued with investigations for the Bob Sandlin Reservoir by Southern Methodist University (SMU) and the University of Texas. SMU also surveyed the location for the Welsch Power Plant on Swauano Creek (Cliff, et al, 1974). An extensive survey, followed by excavations was conducted on Blundell Creek for the Lake Monticello project by McCormick of SMU. In 1973 and 1974 the SDHPT excavated the Alex Justiss Site on SH 49 at Swauano Creek. All these investigations were in the Cypress Basin. Only a limited survey was conducted in the northern part of the county for the A rmy Corps of Engineers channel project on the Sulphur River in connection with the Cooper Dam project

In may, 1980, Wayne Young of the SDHPT excavated the Tankersley Creek Site also in the Cypress Basin. At the present time, a number of surveys are being done for the extension of a lignite mining operation in the southern drainage of White Oak Creek as are surveys for various pipeline and transmission lines which will cross White Oak Creek and Sulphur River. 


\section{TESTING PROCEDURES}

Testing of Site 41TT87 began with a cursory examination of those portions to be affected by the project, particularly those portions to be acquired as additional right-of-way. Since county road, CR 211, divided the site into two parts, the western portion was designated Area I and the eastern half, which contained the major portion of the site, was designated Area II (Fig. 2).

Area I had a substantial ground cover of small trees, sumac, vines, and grass. Fortunately, the highest elevation in this area within the new right-of-way had slightly less ground cover and offered a minimal view of the ground surface. A small prehistoric ceramic sherd and two flakes of a local chert were recovered from this surface. Test Unit 1, a 1x1meter square, was laid out in this semi-open area and oriented approximately parallel to the county road.

This and the subsequent test units were excavated in $10 \mathrm{~cm}$ levels measured from the ground surface. Each level was trowelled to reveal any features. All excavated material was screened through $1 / 4$ inch hardware cloth and all cultural material thus recovered was placed in appropriately labeled bags. All materials were transported to the SDHPT laboratory in Austin for processing and analysis.

The material recovered from Test Unit 1 (TU-1) is summarized in Table 1 It became obvious during the excavation that this location was much disturbed. Level 1 produced an encouraging amount of prehistoric artifacts; 2 dart point bases, a corefragment, 8 pottery sherds, 21 flakes, and two pieces of burned clay. It also contained the expected pieces of modem refuse-in this case, a piece of unbleached glass, a fragment of earthenware, and a cut nail.

TABLE 1. Test Unit 1, Area I.

\begin{tabular}{c|c|c|c|c|c|c|c}
\hline Level & Flakes & $\begin{array}{c}\text { Flaked } \\
\text { Artifacts }\end{array}$ & $\begin{array}{c}\text { Prehistoric } \\
\text { Ceramic } \$\end{array}$ & $\begin{array}{c}\text { Historic } \\
\text { Ceramic }\end{array}$ & Glass & Metal & Other \\
\hline 1 & 21 & 2 & 8 & 1 & 1 & 1 & - \\
2 & 20 & 1 & 3 & 1 & 2 & 3 & - \\
3 & 16 & 2 & 1 & 2 & 7 & 9 & - \\
4 & 12 & 1 & 1 & 1 & 1 & 2 & - \\
\hline \hline
\end{tabular}

The second level contained a nearly complete Gary-like dart point, (Suhm 1962), 200 flakes, 3 pottery shcrds and 12 small pieces of burned clay. The northeast comer of the unit began to reveal a large modern disturbance. This consisted of a lens of ash and charcoal bits with pieces of rusted sheet metal, probably from cans, as well as glass and earthenware fragments and nails.

The third level produced a similar array of artifacts including the proximal portion of a Catahoula arrowpoint (Turner 1985) and another probable Gary base. The disturbance in the northeast comer of the unit continued to produce most of the historic materials. At this point several large ant colonies were uncovered as well as several gopher burrows.

The fourth level was very wet due to the ground water seeping into the unit and it became impossible to effectively trowel the floor or screen the excavated material. However. the amount of historic materials continued and the amount of prehistoric materials decreased. The unit was abandoned to dry out. Unfortunately, heavy rains the following night caused the abandonment to be permanent. The next level would have been the last since since tests with a 1 inch diameter soil probe showed the clay to be only 8 to $10 \mathrm{~cm}$ deeper than the $40 \mathrm{~cm}$ already excavated. 


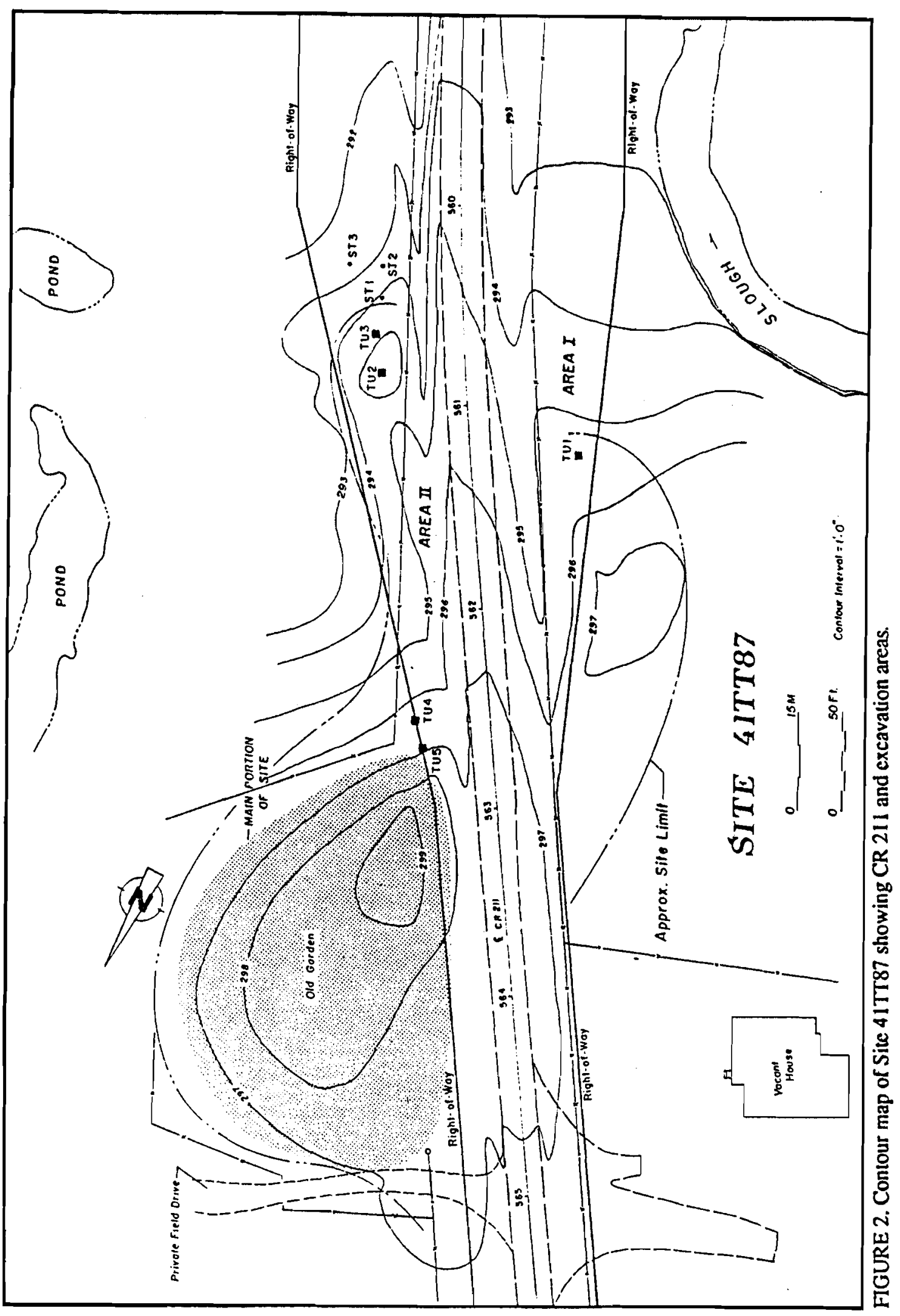


No features other than the lens of ash and historic materials were noted in TU-1. An inspection of Area I showed that considerable erosion, probably associated with farming but possibly the result of the road construction, had occurred. This may be seen on the contour map of the site in Figure 2. Since the remaining portions of Area I which were within the right-of-way limits showed signs of flooding or erosion, no further excavations were conducted. Sampling with the soil probe showed the red clay to be very near the surface. This was also indicated by several areas of standing water.

Test Unit 2 (TU-2) was placed on the east side of CR 211 on the highest elevation included in thenew rightof-way. This area was much clearer that the location forTU-1 but still contained considerable briars, poison ivy and numerous oak seedlings. The unit was $1 \times 1$ meter square and was oriented parallel to the existing right-of-way fence. It was excavated in the same fashion as TU-1 and the recovered materials are shown in Table 2. It should be noted that no twentieth century materials were recovered from this unit. This unit was temporarily abandoned due to heavy rain. It was later completed and excavated to sterileclay. Two Gary dart points were recovered from within a few centimeters of each other. No features were noted but there was considerableevidence of gopher disturbance.

TABLE 2. Test Unit 2, Area II.

\begin{tabular}{c|c|c|c|c|c|c|c}
\hline Level & Flakes & $\begin{array}{c}\text { Flaked } \\
\text { Artifacts }\end{array}$ & $\begin{array}{c}\text { Prehistoric } \\
\text { Ceramics }\end{array}$ & $\begin{array}{c}\text { Historic } \\
\text { Ceramics }\end{array}$ & Glass & Metal & Other \\
\hline 1 & 20 & 1 & 3 & - & - & - & - \\
2 & 36 & 1 & 14 & - & - & - & - \\
3 & 21 & $1^{*}$ & 2 & - & - & - & - \\
4 & 14 & $1^{*}$ & - & - & - & - & - \\
\hline \hline
\end{tabular}

*Dart Point

The third unit, TU-3, was placed just three meters south of TU-2 and was excavated to sterile clay. The clay was found after only three $10 \mathrm{~cm}$ levels were removed. Several pieces of old road surface were found in the firstlevel which showed that the location had been used as either a stockpile or waste site for the county road. The materials are summarized in Table 3 . This unit indicated much disturbance through land use as well as bioturbation.

TABLE 3. Test Unit 3, Area Il.

\begin{tabular}{c|c|c|c|c|c|c|c}
\hline Level & Flakes & $\begin{array}{c}\text { Flaked } \\
\text { Artifacts }\end{array}$ & $\begin{array}{c}\text { Prehistoric } \\
\text { Ceramics }\end{array}$ & $\begin{array}{c}\text { Historic } \\
\text { Ceramics }\end{array}$ & Glass & Metal & Other \\
\hline 1 & 16 & - & 1 & 4 & 5 & 1 & Old Road Mat'l. \\
2 & 24 & - & 1 & 1 & 1 & 1 & - \\
3 & 2 & - & 2 & - & - & - & - \\
\hline
\end{tabular}

Three shovel tests were placed south and east of TU-3 and confirmed that the clay was shallower near the slough and downslope. In all three tests the clay was found at 15 to $20 \mathrm{~cm}$ below the surface.

Testing of the main portion of the site began with TU-4. When the test excavations began, this area was covered by a lush stand of Johnson grass and bull nettles. This was mowed by maintenance forces from the Mount Pleasant SDHPT office. Very little of this part of the the site will be affected because the new right-ofway tapers to match the existing right-of-way. The existing right-of-way is 30 feet left and right of the centerline of CR 211. TU-4 was placed near the east right-of-way near the end of the project. Unfortunately,all of the main portion of the site included in the new right-of-way was also in the existing road-cut and the original construction of SH 26 had removed the upper portions. The existing back-slope appeared to be at about a 6:1 slope so as much as a half meter of the site deposit may have been removed near the road. In the area of TU4 , it appeared that only $20-30 \mathrm{~cm}$ had been removed. 
The upper levels contained considerable modem refuse and roots and some of the prehistoric artifacts recovered may have been redeposited due to slope wash. The materials recovered from this unit are listed in Table 4. Almost all of the recovered artifacts were found on the screen. The exceptions were prehistoric ceramic sherds and the larger flakes recovered from the upper levels.

TABLE 4. Test Unit 4, A rea II.

\begin{tabular}{c|c|c|c|c|c|c|c}
\hline Level & Flakes & $\begin{array}{c}\text { Flaked } \\
\text { Artifacts }\end{array}$ & $\begin{array}{c}\text { Prehistoric } \\
\text { Ceramics }\end{array}$ & $\begin{array}{c}\text { Historic } \\
\text { Ceramics }\end{array}$ & Glass & Metal & . Other \\
\hline 1 & $\mathbf{2 3}$ & - & 11 & - & - & - & - \\
$\mathbf{2}$ & $\mathbf{1 4}$ & $\mathbf{1}^{+}$ & 7 & - & $\mathbf{1}$ & - & - \\
$\mathbf{3}$ & 12 & - & 7 & - & - & - & - \\
$\mathbf{4}$ & 7 & - & 2 & - & - & - & - \\
$\mathbf{5}$ & $\mathbf{4}$ & - & $\mathbf{3}$ & - & - & - & - \\
$\mathbf{6}$ & 9 & $\mathbf{2}^{*}$ & - & - & - & - & cut bone \\
7 & $\mathbf{4}$ & - & - & - & - & - & - \\
8 & $\mathbf{8}$ & - & - & - & - & - & - \\
9 & 7 & - & - & - & - & - & - \\
10 & $\mathbf{8}$ & - & - & - & - & - & nut shells \\
11 & $\mathbf{2}$ & $=$ & - & - & - & - & burned clay (?) \\
\hline \hline
\end{tabular}

${ }^{\dagger}$ Altered Flake *Dart Point

No features were identified in TU-4. Of special interest however, are two dart points from level 6. Both were found on the screen. A small piece of bone which appears to have been cut and ground also came from this level. Several fragmentary pieces of burned nut shell were recovered from level 10 and appear to be either walnut or hickory nut. They are very fragmentary and may have originated at some higher level and fallen into the bottom of the unit. They were found on the screen. A few soft concretionswere found in level 11, the final level for this unit At this point, the soils were very compact and wet. A profile of the south wall of this unit is shown in Figure 3.

Test Unit 5 was placed 3 meters north and 1 meter west of TU-4. This position was barely within the right-ofway but was at a slightly higher elevation. As with the unit before, road construction had removed some of the original site surface. The top two levels excavated were disturbed, with many roots, pieces of modern trash and a considerable amount of charcoal staining, probably the result of burning trash or brush. The materials recovered are listed in Table 5. Level 1 contained $\mathbf{3}$ biface fragments and one probable arrowpoint preform. There were also 3 utilized/al tered flakes and one trimmed flake recovered.

TABLE 5. Test Unit 5, A rea II.

\begin{tabular}{c|c|c|c|c|c|c|c}
\hline Level & Flakes & $\begin{array}{c}\text { Flaked } \\
\text { Artifacts }\end{array}$ & $\begin{array}{c}\text { Prehistoric } \\
\text { Ceramics }\end{array}$ & $\begin{array}{c}\text { Historic } \\
\text { Ceramics }\end{array}$ & Glass & Metal & Other \\
\hline 1 & 64 & $\mathbf{4}^{\star}$ & $\mathbf{3 4}$ & - & 2 & $\mathbf{5}$ & tar Paper \\
$\mathbf{2}$ & 10 & $1^{\dagger}$ & 17 & - & $\mathbf{2}$ & 1 & tar Paper \\
$\mathbf{3}$ & 11 & $\mathbf{1}^{\dagger}$ & $\mathbf{5}$ & - & - & 1 & - \\
$\mathbf{4}$ & 10 & $2^{\prime}$ & 1 & $\mathbf{-}$ & $\mathbf{-}$ & $\mathbf{-}$ & burned clay \\
$\mathbf{5}$ & 8 & $1^{\dagger \dagger}$ & - & - & - & - & - \\
$\mathbf{6}$ & $\mathbf{3}$ & - & - & - & - \\
\hline \hline
\end{tabular}

*ArrowpointPreform 'Utilized Flake ${ }^{\dagger+}$ Biface

The excavation ended at level 6 when only three small flakes were found and the soil matched that of the bottom of TU 4. This dense and compact sand was essentially sterile and was very wet As in all the other tests, there were numerous soft manganese-ferrousconcretions and many solution lines in the walls of the units. 
The profile of the south wall of TU-4,(Fig. 3), shows the ground slope resulting from the road cut The upper zone of dark brown sand contained considerable humus and most of the historic artifacts recovered. There were numerous rodent burrows and other krotivena and only the most obvious are shown in the figure. The mottled light tan sand begins at level 5 and did not appear to be disturbed. Many of the mottles had at their center, soft Mg-Fe concretions.

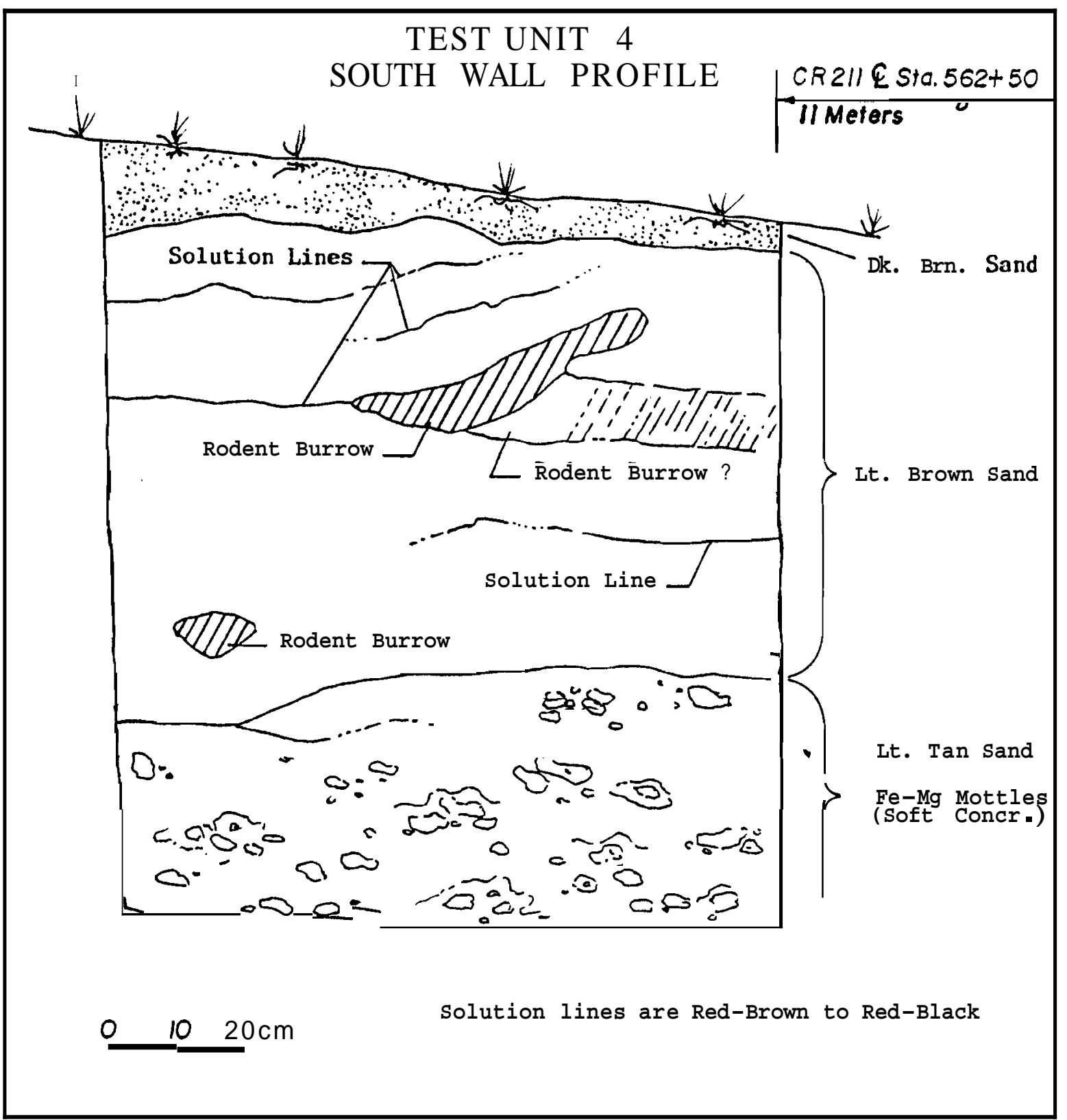

FIGURE 3. Profile of the south wall of Test Unit 4. 


\begin{abstract}
ARTIFACTS
The artifacts recovered from Site 41TT87are typical of those found at sites throughout the area. The historic artifacts, cut and wire nails, glass, ceramics, and bits of sheet metal, can be dated from the recent past to the late 1800 s.

A surface collection of the exposed portions of the site was made prior toexcavation. Only a small portion of the surface was visible due to the heavy vegetation but a private field drive across the north end of the site produced a few flakes of chert and two Gary points. The west side of the road, Area I, was overgrown except for the small area near TU-1.

Most of the prehistoric artifacts recovered consist of flakes of Potter or Ogalalla Chert (Mallouf 1976). These were usually small, the average being less than $2 \mathrm{~cm}$ in length. Some show signs of alteration, probably through use as a cutting or scraping tool.
\end{abstract}

\title{
HISTORIC ARTIFACTS
}

Metal: (N=29)

Of the 29 pieces of metal recovered, most were fragments of tin cans. There were 10 cut-nails recovered but only one wire nail. Other historic materials included 3 fence staples, a short length of insulated copper wire and a modem clothes-pin spring. Nine of the cut-nails and 8 of the sheet metal fragmentscame from TU-1.

Ceramics: $(\mathrm{N}=10)$

A total of 10 historic ceramic artifacts were recovered. Of these, 8 were earthenware. One of these was a small piece of stencilware dating from the 1850s. Five were white earthenwareand 2 specimens were plain stoneware, probably from a large crock or jar.

Glass: $(N=24)$

There were 24 pieces of glass recovered at the site, all of them fragments. Only 5 were manganese bleached. Five were unbleached, 5 were selenium bleached, 7 were amber colored and 1 was dark olive-green. Most came from TU-1 and TU-3.

\section{PREHISTORIC ARTIFACTS}

\section{Chipped Stone}

Arrowpoint ( $=1$, Fig. 4A)

Only one arrowpoint was recovered during the test excavations. This is a proximal portion of a Caiahoula type recovered from TU-1, level 3, but found on the screen. It is well made from a medium gray chert.

Arrowpoint preform ( $\mathrm{N}=1$,Fig. 4B)

A probable arrowpoint preform was found in TU-5, Level 1. Both faces show trimming to a basic shape. 


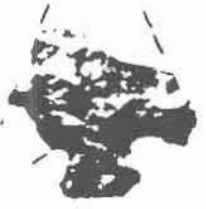

A
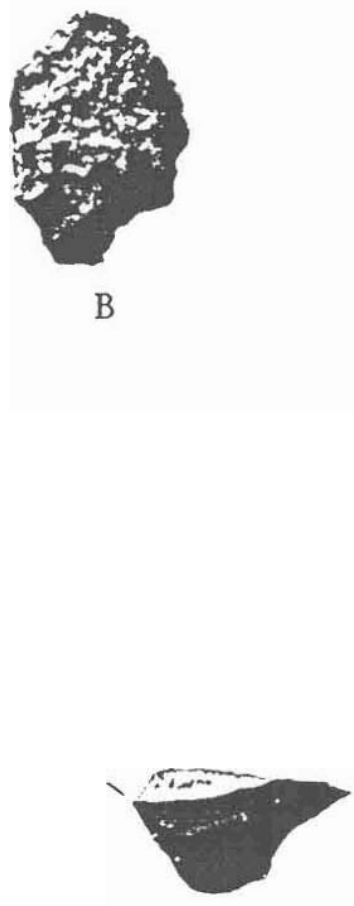

F

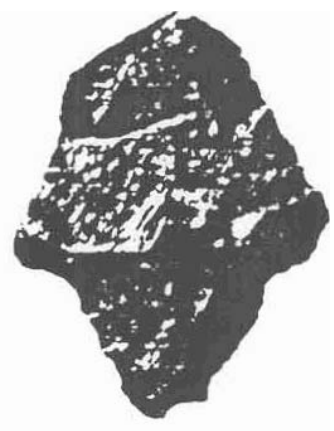

C

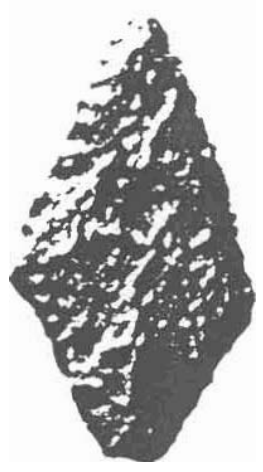

D

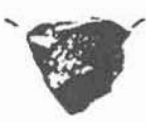

G

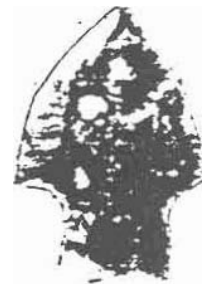

$\mathrm{H}$
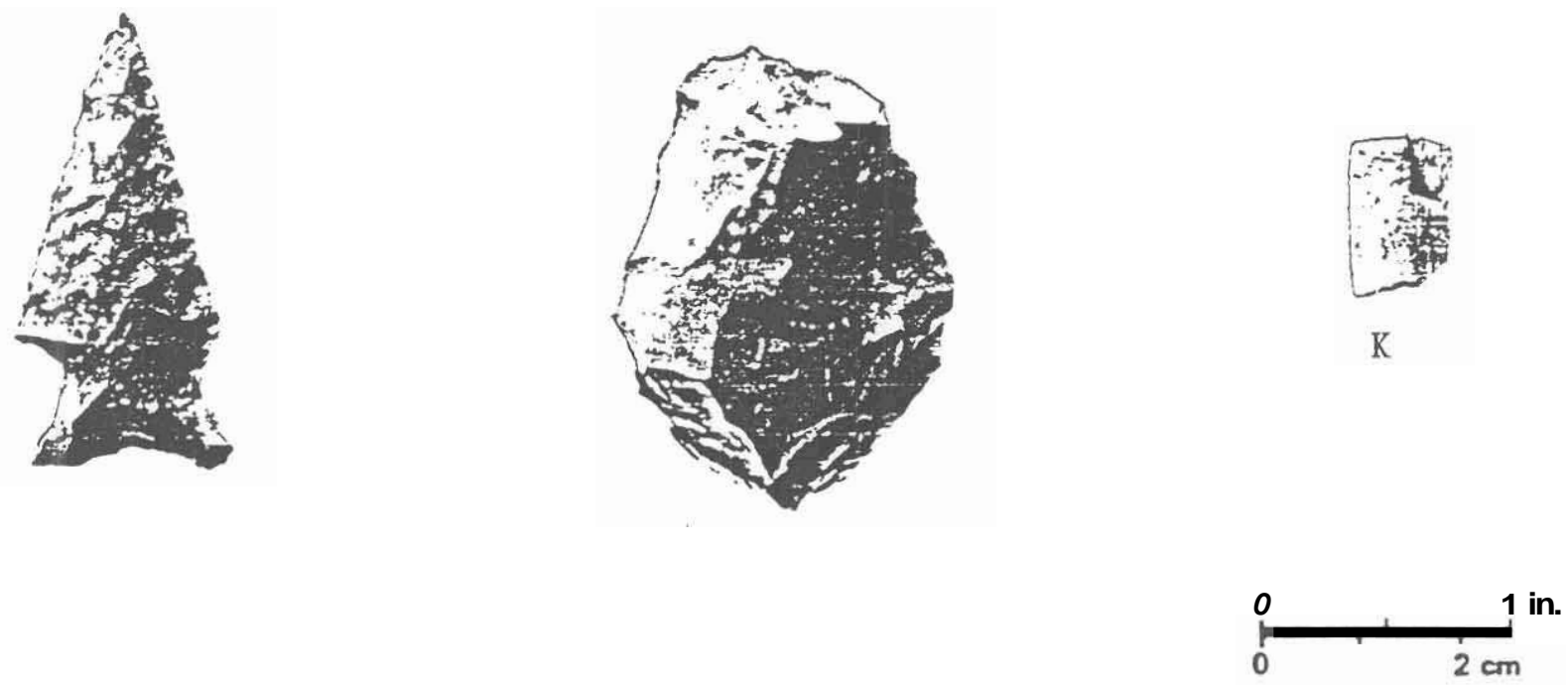

FIGURE 4. Chipped stone tools and bone from Site41TT87. 
Dart Points

Gary (N=4, Fig. 4C, D)

Two of these artifacts were found during the surface collection on the extreme north end of the site in the private field drive. The 2 specimens illustrated came from TU-2, levels 3 and 4, from what appears to have been a gopher cache. One of these, specimen $\mathrm{C}$, has obvious impact scars on both faces.

Gary-like (N =1, Fig. 4E)

This oddly shaped tool appears to have been a Gary dart point which has been severely reshaped. It came from TU-1, level 2 in a disturbed context.

Gary dart point bases (N=3, Fig. 4F, G)

These two artifactsare typical of the Gary type base. The were found in TU-2 and TU-1, respectively, bothin level 1.

Untyped Dart Points (N=2,Fig. 4H, I)

Two dart points which do not fall within any type were recovered from TU-4, level 6 . This was the deepest level from which any flaked tools were recovered. Both specimens are well made. The larger of the two, specimen G, is made of a mottled gray chert, possible heat-treated Ogalalla Chert, and has one beveled edge on the reverse side. The other specimen is made from a gray, almost translucent, fine-grained material with small white inclusions.

Both of these dart points, as well as several flakes from the level, have small dark stains and deposits, especially in the step fractures along the edges. These deposits were examined with a binocular microscope and were also found to be slightly soluable in naptha. They were determined to be road-oil or asphalt contaminations probably resulting from pot hunting activities or road construction.

Fragments $(\mathrm{N}=5)$

Of the five biface fragments recovered, four appear to be basal fragments of small dart points. Three of these are probably from the Gary type. One fragment of a midsection edge was found.

Thick Biface ( $\mathrm{N}=1$, Fig. 4J)

This thick biface appears to have been chipped from a small cobble. It was found in TU-5, level 5,

Bone

Cut Bone ( $\mathrm{N}=1$, Fig. 4K)

This is a piece of bone which was cut and the edge apparently ground smooth. It came from TU-4, level 6.

Ceramics

A total of 124 individual ceramic sherds were recovered from the 5 test units and surface of the site. Several of these were reconstructed so that a total of 108 sherds were available for analysis. In general these sherds represent the Caddo IV period (Davis, 1970).

The great majority of the sherds, $93.5 \%$, are body sherds and of these $77.8 \%$ are plain. Of the 7 rim sherds recovered, five are decorated. Most of the sherds recovered are small; thoseillustrated are among the largest. Decorations consist of incised lines, usually parallel, engraved lines, applique and slipping. Only one redslipped sherd was found. Absent are sherds with brushing or punctate motifs. Several sherds were tempered with bone combined with the more usual clay-grit. Colors vary from light tan to near black with buff and brown being the most common. 


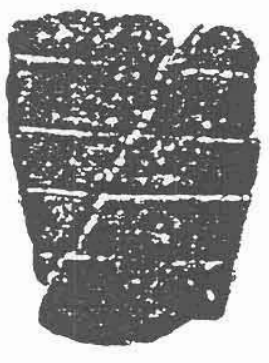

A

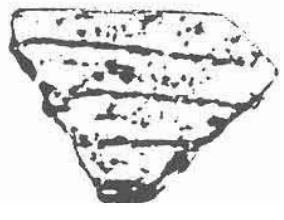

B

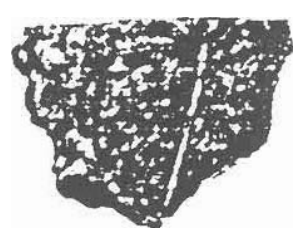

C

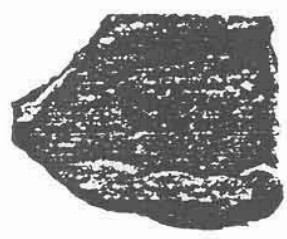

D

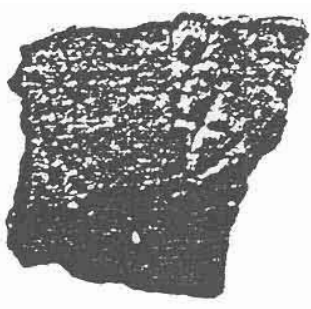

$\mathrm{E}$

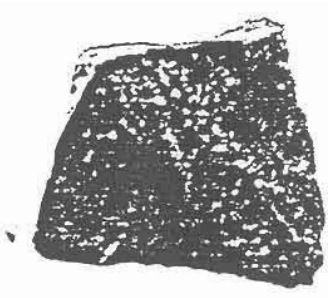

F

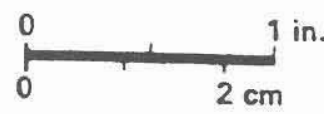

FIGURE 5. Ceramic artifacts from Site 41TT 87. 
Rim Sherds (N=7, Fig. 5A-D)

These 4 specimens are rim sherds and represent all but 1 of the decorated rim sherds. Specimen A is the least typical. It has parallel engraved lines which apparently encircled the rim of the vessel. The rim itself is almost gone due to gnawing by rodents. It was probably quite thin originally and was straight It may represent an A very type vessel (Suhm and Jelks 1962). Specimens B and C are more typical of the collection. Both are thick $(0.8 \mathrm{~cm})$ with rounded lips. Both have incised parallel lines. Specimen D appears to have been from a neck-banded vessel.

Body Sherds (N=101, Fig 5E, F)

These 2 pieces are examples of decorated body sherds. Specimen $E$ is engraved and is from a carinated bowl, possibly of the Ripley Engraved type (Suhm and Jelks 1962). Specimen F is the only example of applique recovered. It was found in TU-4, Level 2. 


\section{SUMMARY AND RECOMMENDATIONS}

Site 41TT 87 is primarily a prehistoric site. although one with several components, the most obvious being the late ceramic period. However, the site may contain some intactelements of an earlier Woodland occupation as well as the late Archaic Period. In addition, there is the possibility of late nineteenth century materials being intact but not within the project limits. Since most of the historic materials were recovered from the west side of CR 211, Area I, they are most likely associated with the occupants of the 1920s house.

All areas tested showed disturbances from previous road construction and gophers. The amount of disturbance to the main portion of the site, the area previously used as a garden and barn site, could not be determined by testing the small amount included in the right-of-way required for this project. It is likely that the disturbances are limited to the plow zone and the gopher burrows.

The quantity of artifacts recovered suggests a relatively rich site although most of the ceramics came from the upper 2 levels, levels which contained recent deposits and were the most disturbed. Evidence of gopher disturbance was noted in every unit.

The amount of right-of-way required for the project limited the investigations but will also limit the impact of the project on the site. As can be seen in Figure 2, the area to be acquired as additional right-of-way is generally away from the main portion of the site. This is very near the terminus of the project where the new roadway will merge with the existing county road Test units TU- 2 and TU- 3 and the 3 shovel tests were all shallow. TU-2 and TU-3 both contained natural and artificial disturbances.

It is likely that those portions outside the project limits may be eligible for consideration as State Archaeological Landmarks however those portions inside the right-of-way are not.

It is recommended that no further investigations be conducted at Site 41TT87 at this time. 


\section{REFERENCES CITED}

Cliff, Maynard. Carol Carter, and Linda Verrett

1974 Archaeological Survey of the Welsch Power Plant. Report submitted to Southwestern Electric Power Company, Shreveport, La., by Southern Methodist University.

Davis, E. M.

1970 Archaeological and Historical Assessment of the Red River in Texas, In Archaeological and Historical Resources in the Red River Basin, edited by H. A. Davis. pp 27-65. Arkansas Archeological Survey Research Series 1.

Fenneman, Nevin M.

1938 Physiographyof Eastern United States. McGraw-Hill. New York and London.

Mallouf, Robert L.

1976 Archeological Investigations at Proposed Big Pine Lake, 1974-1975, Lamar and Red River Counties, Texas. Texas Historical Commission Archaeological Survey Report 18, Austin.

Suhm, Dee Ann, and Edward B. Jelks

1962 Handbook of Texas Archeology: Type Descriptions. Texas Archeological Society Special Publication, and Texas Memorial Museum Bulletin 4, Austin.

Turner, Ellen Sue, Thomas R. Hester

1985 A Field Guide to Stone Artifacts of Texas Indians, Texas Monthly Press, Austin. 